\title{
The Correlation of Tenses in English and Albanian Time Clauses
}

\author{
Erjon Agolli \\ English Language Department \\ University of Tirana \\ agollierjon@yahoo.com
}

\section{Doi:10.5901/ajis.2013.v2n2p311}

\section{Abstract}

This paper discusses the typical tenses used in the main clause and time clause, and the semantic-grammatical interpretations indicated by such tense correlations. According to the results of the corpus analysis, the most frequent tense correlation in time clauses of anteriority is past perfect-past simple; simultaneity clauses, on the other hand, are usually characterized by the combination of past continuous-past simple; while relations of posteriority are usually expressed by the correlation of past simple-past simple. Thus, we can say that the correlation of tenses and moods of predicates is of high importance in strengthening temporal relations in complex sentences with time clauses.

Keywords: Time clauses, semantic relations, tense correlation

\section{Introduction}

All tenses express relations between times. In John had already left, the past perfect form had left expresses two relations: the time of the situation of leaving is represented as anterior to a time of orientation, which is itself anterior to the temporal zero point (the time of speaking) (Declerck, 1996). In Albanian, the temporal meaning of anteriority, posteriority, or simultaneity becomes clear by the lexical meaning of the predicates and the correlation of tenses (Totoni, 2000). Similarly, there is a certain regularity in the use of tenses in English temporal clauses which is dependent, on the one hand, on the lexical meaning of the finite verbs occurring in these clauses and, on the other hand, on the objective relations of the two actions in the extralinguistic reality (Breithutova, 1968). For example, when you are talking about the past or the present, the verb in the time clause has the same tense that it would have in a main clause or in a simple sentence (Collins cobuild English grammar, 1992):

(1) I was standing by the window when I heard her speak.

But this isn't the case when talking about the future. Indeed, in time clauses referring to the future, English prefers the present tense (Yamagashira, 2003), and Albanian uses a predicate in the present tense of the subjunctive mood in the time clause (Çeliku et al., 2002), instead of a corresponding future form:

(2) When the school bell rings, students will exit the historic Catholic high school.

(3) Ai ta tregon vendin ty, posa të kthehet nga ushtria.

What is more, in time clauses of anteriority, although before implies that the head clause activity is anterior to the activity referred to in the before-clause, it is possible to use a past perfect tense in the time clause (Declerck, 2002):

(4) I bought a car before he had bought one.

While agreeing on the fact that the correlation of tenses is not an absolute means of expressing temporal relations, I evidence that there do exist some regular patterns and that, in certain circumstances, they become determinant in expressing these temporal relations. The article also sheds light on the main distinctions between typical tense correlations in English and their Albanian equivalents, attempting to offer a new comparative approach to this grammatical issue, which will hopefully benefit both teachers and learners of English, as well.

\section{Materials and Methods}

The corpus taken into consideration for the analysis is composed of 360 English complex sentences with time clauses extracted from the novel "The summer before the dark" by Doris Lessing, contrasted to their Albanian equivalents taken 
from the translated version "Vera para errësirës" by Merita Meçe. Complex sentences with time clauses make up 12.000 words, out of a total corpus of about 90.000 words comprised in the novel.

To facilitate their study and analysis, all complex sentences with time clauses found in the original text and in the translated one have been stored in computer documents, where they have been classified according to the semantic relations they express, as well as the tenses used both in the time clause and the matrix clause. The processing of these quantitative data, has led to very valuable conclusions on the tense correlations occurring more frequently in complex sentences with time clauses. The data have also been used in the qualitative aspect of the paper, where the sentences extracted from the corpus have been used to illustrate with examples certain theoretical points drawn by closely studying and analyzing each sentence case by case.

\section{Results and Discussions}

Although a variety of tense correlations were identified in the corpus, I have come up with a set of regular patterns that appear to be more frequent, and drawn general theoretical conclusions on the semantic and functional characteristics governing the use of tenses in time clauses of anteriority, simultaneity, and posteriority:

\subsection{The correlation of tenses in anteriority clauses}

Taking a quick look at the following table, we can easily notice that the only possible combination of tenses in whenclauses in the corpus is past perfect-past simple, while in before-clauses one of the most frequently used patterns of tense correlations is past simple-past simple. This clearly shows that the tense correlation in when-clauses plays an essential role in expressing relations of anteriority, since the conjunction when denotes only general temporal meaning, unlike the conjunctions before or until, which are specialized conjunctions of anteriority and can be used with a greater variety of tense correlations:

Table l: Anteriority clauses and tense correlations

\begin{tabular}{|c|c|c|c|}
\hline \multirow[b]{2}{*}{ Tense Correlations } & \multicolumn{3}{|c|}{ Anteriority } \\
\hline & 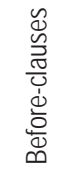 & 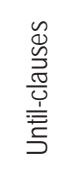 & $\begin{array}{l}0 \\
\mathbb{N} \\
0 \\
\frac{\pi}{0} \\
1 \\
\frac{1}{0} \\
\frac{N}{3}\end{array}$ \\
\hline Past Simple - Past Simple & $50 \%$ & $42 \%$ & \\
\hline Past Perfect - Past Simple & $8 \%$ & $10 \%$ & $100 \%$ \\
\hline \multicolumn{4}{|l|}{ Past Continuous - Past Simple } \\
\hline \multicolumn{4}{|l|}{ Past Simple - Past Continuous } \\
\hline Present Simple - Present Simple & $8 \%$ & $19 \%$ & \\
\hline Past Perfect - Past Perfect & $8 \%$ & $10 \%$ & \\
\hline \multicolumn{4}{|l|}{ Past Continuous - Past Continuous } \\
\hline Past Simple - Past Perfect & $6 \%$ & $9 \%$ & \\
\hline Will - Present Simple & $12 \%$ & $10 \%$ & \\
\hline Would - Past Simple & $8 \%$ & & \\
\hline
\end{tabular}

In English, we can often notice the correlation of past perfect in the main clause and past simple in the before- and when-clauses to emphasize the fact that the action in the main clause developed earlier than the action in the dependent clause. This case is also characteristic for the Albanian language with the conjunction kur followed by the use of perfect forms in the main clause and simple verb forms in the subordinate clause, while time clauses with the conjunctions para se, përpara se always have the predicate in the subjunctive mood (Çeliku et al., 2002), as in (6), below:

(5) a. She had already given her address to the taxi man when she remembered that she had no right to it... (Lessing, 2009) 
b. Ajo tashmë i kishte dhënë adresën e saj shoferit të taksisë kur u kujtua që nuk mund të shkonte atje... (Lessing, 2010)

On the other hand, if the main clause refers to an event that will happen in the future before the event presented in the time clause, the present simple is used in the time clause and a future form or present simple in the main clause:

(6) a. I will let you know before I arrive. (Lessing, 2009)

b. Do t'ju njoftoj para se të vij. (Lessing, 2010)

In the corpus, I identified a variety of correlations with the time conjunctions till and until, which also denote anteriority:

(7) a. The children ran with her in crowds through the dust until she stepped into the hotel. (Lessing, 2009)

b. Fëmijët vrapuan me të në grupe nëpër muzg deri sa ajo hyri në hotel. (Lessing, 2010)

(8) a. I think you ought to go to bed and stay there till you are better. (Lessing, 2009) 2010)

b. Unë mendoj që ti duhet të shkosh në shtrat dhe të qëndrosh atje deri sa të bëhesh më mirë. (Lessing,

With the Albanian corresponding conjunctions derisa, gjersa, and sa, anteriority is expressed in the three time scales (past, present, future), supported by the correlation of predicates with the same tense and mood in both clauses, or the subjunctive mood in the time clause (Totoni, 2000).

\subsection{The correlation of tenses in simultaneity clauses}

A wider distribution of tense correlation patterns was noticed in simultaneity clauses. However, while-clauses are commonly characterized by the combination of past continuous-past simple, and as-clauses are more frequently used with a correlation of past simple-past simple. See, table II below:

Table II: Simultaneity clauses and tense correlations

\begin{tabular}{|c|c|c|c|}
\hline \multirow[b]{2}{*}{ Tense Correlations } & \multicolumn{3}{|c|}{ Simultaneity } \\
\hline & 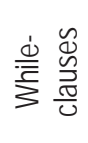 & 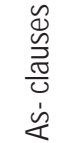 & 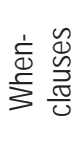 \\
\hline Past Simple - Past Simple & $30 \%$ & $62 \%$ & $25 \%$ \\
\hline Past Perfect - Past Simple & $9 \%$ & & $20 \%$ \\
\hline Past Continuous - Past Simple & $49 \%$ & $23 \%$ & $32 \%$ \\
\hline Past Simple - Past Continuous & $5 \%$ & $10 \%$ & $5 \%$ \\
\hline Present Simple - Present Simple & & $5 \%$ & $9 \%$ \\
\hline Past Perfect - Past Perfect & & & $9 \%$ \\
\hline Past Continuous - Past Continuous & $7 \%$ & & \\
\hline
\end{tabular}

In the English language, the conjunctions when and whenever are used with verb forms in the present simple or past simple in both clauses to describe complete simultaneity of the two repeated events:

(9) a. He got into a fury when/whenever poor people anywhere were mentioned. (Lessing, 2009)

b. Ai xhindosej kur/sa herë që përmendeshin njerëzit e varfër. (Lessing, 2010)

As we can see above, the connotation of a repeated action, in Albanian is also strengthened by the use of the same tenses in both clauses.

The conjunctions kur, ndërkohë që, ndërsa in Albanian, as well as the conjunctions when, while, and as in English, can describe a specific unrepeated event that develops in the background of another event, occurring in a variety of tense correlations:

(10) a. The horse... drank while the lorry driver was dipping his empty oil can right under its nose. (Lessing, 2009) (past simple-past continuous)

b. Kali ...pinte ndërsa shoferi i kamionit po shpëlante kutinë bosh të vajit mu pushtë hundës së tij. (Lessing, 2010) (imperfect- imperfect)

(11) a. He stood by her while she telephoned. (Lessing, 2009) (past simple- past simple) 
b. Ai qëndronte pranë saj ndërkohë që ajo telefononte. (Lessing, 2010) (imperfect- imperfect)

Time clauses with the conjunction as long as, although few in number in the corpus, usually occur in a combination of will/would- present/past simple to express duration along the development of the events i.e. these clauses show that the situations stated and finished together. Whereas, the conjunction sa kohë që/aq kohë sa in Albanian is supported by the same verb forms in both clauses, as below:

(12) a. It was clear that these two would continue..., as long as they were together. (Lessing, 2009)

b. Ishte e qartë që këta të dy do të vazhdonin..., për aq kohë sa ata të ishin bashkë. (Lessing, 2010)

\subsection{The correlation of tenses in posteriority clauses}

As we can see from the following table, temporal relations of posteriority are usually expressed by the correlation of the same tenses in the main clause and in the time clauses. An interesting finding, though, is the combination of past simplepast simple in all the examples of time clauses with the conjunction as soon as in the corpus. This correlation of tenses stresses the idea of two short actions that happened one after the other:

Table III: Posteriority clauses and tense correlations

\begin{tabular}{|c|c|c|c|c|}
\hline \multirow[b]{2}{*}{ Tense Correlations } & \multicolumn{4}{|c|}{ Posteriority } \\
\hline & 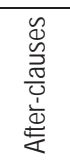 & 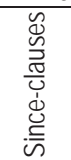 & 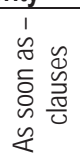 & 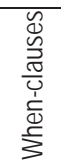 \\
\hline Past Simple - Past Simple & $5 \%$ & $7 \%$ & $100 \%$ & $40 \%$ \\
\hline Past Perfect - Past Simple & & $15 \%$ & & \\
\hline Past Continuous - Past Simple & & $7 \%$ & & \\
\hline \multicolumn{5}{|l|}{ Past Simple - Past Continuous } \\
\hline \multicolumn{5}{|l|}{ Present Simple - Present Simple } \\
\hline Past Perfect - Past Perfect & $30 \%$ & $50 \%$ & & $7 \%$ \\
\hline \multicolumn{5}{|l|}{ Past Continuous - Past Continuous } \\
\hline Past Simple - Past Perfect & $65 \%$ & $21 \%$ & & $29 \%$ \\
\hline Will - Present Simple & & & & $7 \%$ \\
\hline Would - Past Simple & & & & $17 \%$ \\
\hline
\end{tabular}

With after-clauses, the predicate in the dependent clause can be in the past simple or in the past perfect to refer to a completed action in the past and to emphasize that the event in the main clause followed it. The conjunction when can be used for the same function especially followed by perfect forms. Past Perfect (më se e kryera) in the subordinate clause is also common with Albanian specialized conjunctions of posteriority si, pasi, (mbasi):

(13) a.When/after everyone had scattered across the world, she joined that class of hotel guests. (Lessing, 2009) b.Kur/pasi të gjithë ishin shpërndarë nëpër botë, ajo iu bashkua atij grupi mysafirësh të hotelit. (Lessing, 2010)

Meanwhile, if we mention an event in the main clause that will happen after an event presented in the time clause, we use present perfect tense in the time clause, not future perfect tense (Collins, Cobuild English grammar, 1992). While in Albanian, when the situations develop in the future, combinations of future forms in the main clause and perfect forms of the subjunctive mood in the subordinate clause are possible (Totoni, 2000):

(14) a. After/When they have had supper, they will come and see me. (Lessing, 2009)

b. Pasi/kur të kenë ngrënë darkë, do të vijnë të më takojnë. (Lessing, 2010)

After analyzing all examples with the conjunction as soon as found in the corpus, as mentioned above, the most frequent tense correlation was past simple - past simple adding the notion of immediate succession in time of the two events; similarly, the conjunctions sapo, posa, porsa express immediate posteriority in Albanian with a combination of the same verb forms in both clauses:

(15) a. As soon as they reached the flat, Maureen ran off. (Lessing, 2009)

b. Sapo arritën në apartament, Maurini u largua. (Lessing, 2010) 
The conjunction of the English language (ever) since is used to explain that a situation started to exist at a certain time specified in the time clause, and still exists. In this case, past simple is usually used in the time clause and present perfect in the main clause, or past perfect-past simple/past perfect, if this time relation existed in the past. In Albanian language, I noticed that që kur (nga) is used with perfect forms in the subordinate clause:

(16) a. But he had grown older since she saw him last. (Lessing, 2009)

b. Por ishte plakur që nga hera e fundit që ajo e kishte parë. (Lessing, 2010)

\section{Conclusions}

In conclusion, we can say that the semantic content of the time conjunction is of high importance when it comes to expressing relations of anteriority, simultaneity, and posteriority. Nonetheless, these temporal relations could be unclear unless they were strengthened by the correlation of tenses and moods of predicates.

Thus, for example, in order to express anteriority in English and Albanian, we often use predicates in perfect forms in the main clause. This makes sense, for the use of perfect forms emphasizes the fact that the action in the main clause is completed earlier than the action presented in the time clause. At this point, the use of perfect forms becomes almost obligatory especially with the conjunction when/kur, which is not a specialized conjunction of anteriority.

The reversed tense correlation pattern (past simple-perfect form) is used in posteriority clauses, where the use of the perfect forms in the time clause infers that the action in the time clause precedes that in the matrix clause.

Another interesting fact is the use of present simple in the time clause to refer to a future action; a phenomenon that, in Albanian, is made possible by the use of the subjunctive mood.

\section{References}

Breithutova $\mathrm{H}$ (1968), The function of tenses used in modern English temporal clauses. Brno Studies in English, 7, 129-148.

Collins cobuild English grammar (1992), London: HarperCollins Publishers.

Çeliku M, Domi, M, Floqi S, Mansaku S, Përnaska R, Prifti S, Totoni M (2002), Gramatika e gjuhës shqipe (sintaksa). Tiranë: Akademia e shkencave.

Declerck R (2002), Tense and modality in English Before-clauses. EBSCO Publishing, 720-744.

Declerck R (1996), Tense choice in adverbial when clauses. Linguistics, 34, 225-261.

Lessing D (2009), The summer before the dark. First Vintage International Kindle Edition.

Lessing D (2010), Vera para Errësirës. Tirana: Skanderbeg Books.

Totoni M (2000), Fraza me nenrenditje. Tirana: SHBLU.

Yamagashira $\mathrm{H}$ (2003), Adverbial clauses of time in the future. Toso, 33, 149-152. 
